
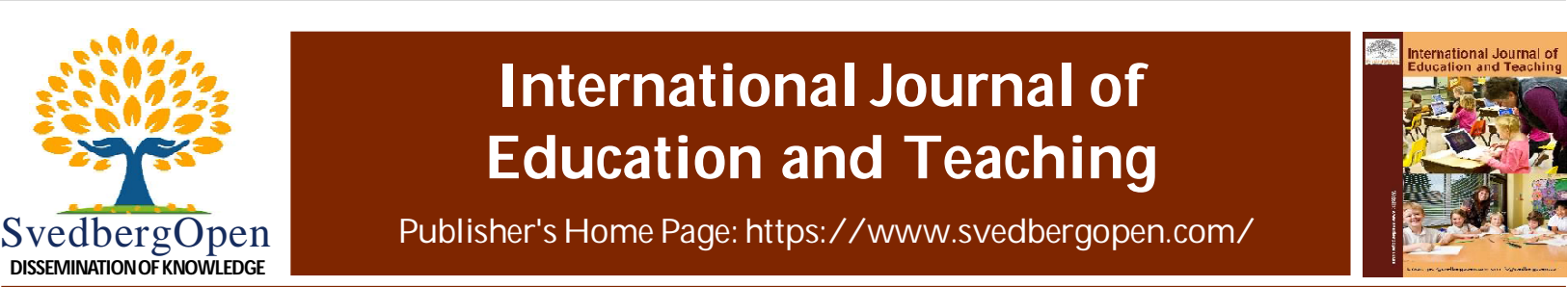

Research Paper

Open A ccess

\title{
The influence of self-efficacy, social economics of parents and learning motivation toward interests of continuing to higher education
}

\author{
Nabilla Hanum Erwananda ${ }^{1 *}$ and Osly Usman, M. Bus ${ }^{2}$ \\ ${ }^{1}$ Student of the Faculty of Economics, State University of Jakarta, Indonesia. E-mail: hanumnabilla20@ gmail.com \\ ${ }^{2}$ Lecturer of the Faculty of Economics, State University of Jakarta, Indonesia. E-mail: oslyusman@unj.ac.id
}

\section{Article Info \\ Volume 1, Issue 1, March 2021 \\ Received : 04 November 2020 \\ Accepted : 14 January 2021 \\ Published : 05 March 2021}

doi: 10.51483/IJEDT.1.1.2021.29-41

\begin{abstract}
This study aims to determine whether the influence of the influence of self-efficacy, social economics of parents, and learning motivation of interest in continuing to higher education. This research was conducted for two months from April to May 2020. The research method used was a survey method with a causality approach. The population in this study was students, amounting to 201 respondents. Data collection techniques using literature and questionnaire techniques. Data analysis techniques using SPSS 22.0 and AMOS 22.0 with Structural Equation Analysis (SEM). The results show that each variable has an influence on the interest in continuing to higher education. So it can be said, if the higher the self-efficacy, the higher will also be the interest in continuing to higher education. Social economy also influences interest in continuing to higher education. Likewise with the higher learning motivation, the higher will also be the interest in continuing to higher education. The above description shows that there is a joint and significant influence between self-efficacy, social economy of parents, and learning motivation.
\end{abstract}

Keywords: Self-efficacy, Social economy of parents, Learning motivation, Interest in continuing to higher education

(C) 2021 International Journal of Education and Teaching. This is an open access article under the CC BY license (https://creativecommons.org/licenses/by/4.0/), which permits unrestricted use, distribution, and reproduction in any medium, provided you give appropriate credit to the original author(s) and the source, provide a link to the Creative Commons license, and indicate if changes were made.

\section{Introduction}

Education is an important factor for the progress of a country. The progress of a country is seen from the quality of its human resources. Qualified human resources can be produced from good and successful education. Moreover, in this day and age, the quality of human resources is very important in order to be able to compete and not be undermined by technology. Each country certainly pays great attention to creating the best education system possible so that later it can produce quality human resources. No exception in Indonesia.

Indonesia itself education is divided into several levels ranging from play groups to the highest, namely universities. Where a student who has completed his studies in elementary school, junior high school, and senior high school can continue studying to get a bachelor's degree at a tertiary institution. Higher education is a level of education after secondary education that includes diploma programs, undergraduate programs, master's programs, doctoral programs, and professional programs, as well as specialist programs, where higher education is carried out in a tertiary institution (Law No. 12 of 2012 concerning Higher Education).

\footnotetext{
* Corresponding author: Nabilla Hanum Erwananda, Student of the Faculty of Economics, State University of Jakarta, Indonesia. E-mail: hanumnabilla20@gmail.com
} 
But in reality, not all students at the high school level continue their studies to college. Deputy for Education and Religion Coordination of the Coordinating Ministry for Human Development and Culture Agus Sartono said, every year the number of high school/vocational school graduates is above 3.5 million people. This is not comparable to the capacity in tertiary institutions of 1.8 million people per year.

In addition to not being able to compare the capacity of tertiary institutions with students graduating from high school, students' interest is also a factor of whether a student will continue their studies or not. Interest in continuing studies to tertiary institutions is a tendency that directs students to continue their studies to tertiary institutions after graduating from high school accompanied by feelings of pleasure. The interest of students in continuing their studies to tertiary institutions can be seen from the attitudes of participants who begin to put and focus their attention on a matter that becomes a desire that is realized by an effort to dig up information about the college they want.

\section{Literature Review}

Factors that can arouse such interest as expressed by (Sardiman, 2011) that, interest does not arise suddenly/ spontaneously, but rather arises from participation, experience, habits during study and work. Interest is the soul's tendency which is relatively sedentary to one's self and is usually accompanied by feelings of pleasure (Muhammad Fathurohman, 2012).

A student's interest in continuing to college does not just emerge. But there are factors that foster this interest. These factors are self-efficacy, socioeconomic parents and also motivation to learn. These three factors are very influential on a student's interest to continue studying in college.

Students' interest in continuing their education to college is influenced by various factors. Opinion (Djali, 2012) categorizing these factors into internal factors and external factors. Internal factors include: (1) health, (2) intelligence, and (3) motivation. While external factors include: (1) family, (2) school, (3) community and (4) surrounding environment.

The first factor that influences a student's interest in continuing their studies to college is self-efficacy.

According to Kreitner (2010) defines self-efficacy as a belief in one's own ability to deal effectively with problemsolving. Self-efficacy also means believing that you are able to succeed and succeed. They believe that having energy (motivation), resources (situational factors), understanding the right actions (role perception) and competence (ability) to do the task.

The higher the self-efficacy a student has, the higher the interest in continuing to college. Because with high selfefficacy a student will have confidence in his ability to achieve success. Therefore, the factor of self-efficacy is very influential on a student's interest in continuing to college.

Conversely, if students themselves feel unsure of themselves will reduce their interest in continuing to college. Because these students already feel insecure first. In line with the opinions expressed by

According to Slameto (2010) explain that interest is a feeling of preferability and a sense of interest in a thing or activity, without being told. Interest is basically the acceptance of a relationship between oneself and something outside of oneself. The stronger or closer the relationship, the greater the interest that arises. The students' interest to continue their studies to college is intended to be interested and the tendency of students to choose to continue to college as a continuation after graduating from high school. Where the tendency of attraction causes feelings of pleasure, and is based on feelings of need so that students consider continuing education to college is an important thing for him.

The second factor that influences students 'interest in going to college is the parents' social economy.

Higher education institutions in Indonesia are divided into state tertiary institutions, tertiary institutions, and private tertiary institutions. As we know, private tertiary institutions are generally single tuition that must be paid more expensive than public tertiary institutions or service associations. This is one of the reasons prospective students who do not get or qualify in state and tertiary institutions of higher education think twice in college because they see the socioeconomic of parents. They prefer to work to help the family economy than to go to college which has to pay.

According to Gerungan (2009) states that the conditions of socioeconomic of family play an important role in growth and development so that they have a wider opportunity to develop their skills. Nike Pratiwi Suciningrum (2015) states that socioeconomic status can be measured through the level of education, type of work, income and wealth that has owned. Abdullah (2010) suggested that, children have broader opportunities to develop knowledge and a variety of physical abilities with the economic support of parents. 
Another factor that also affects a student's interest in continuing to college is learning motivation. As we know, learning motivation is an encouragement from within a student to learn as well as possible.

Meanwhile according to Sadirman (2014) the word "motive" is defined as an effort to encourage someone to do something. Motives can be said as a driving force from within and within the subject to carry out certain activities in order to achieve a goal. Even motives can be interpreted as an internal condition (preparedness). Starting from the word "motive", then motivation can be interpreted as a driving force that has become active.

With the motivation of learning possessed by a student in learning, then he will try his best to study until college. The high motivation to learn will influence and encourage students to reach their dreams. Conversely, if there is no motivation of a student in learning the learning activities he does are not optimal and tends to be done half-heartedly. Therefore the learning motivation factor is very influential on the interest in continuing to college.

\section{Theoretical basis}

\subsection{Interest in continuing to college}

Interest in continuing to college is an interest that arises in a student to continue his studies up to the level of college. This interest does not necessarily arise spontaneously, but there are several factors that influence it. Both internal and external factors.

According to Muhibin (2009) interest in continuing study to tertiary institutions is the interest of students to continue their studies to tertiary institutions that grow consciously within these students. This interest causes students to pay more attention to the tertiary institution they will attend. Interest is basically the acceptance of a relationship between oneself and something outside of oneself. The stronger or closer the relationship, the greater the interest.

According to Agus M H in his book, Tips for Successful Study in Higher Education. In terms of studying in higher education, interest is the interest to provide time, energy, effort to absorb and organize information, knowledge and skills that we receive in various ways.

Based on the description above, it can be concluded that the interest in continuing to higher education is the tendency or desire of students to continue their studies to higher education accompanied by feelings of pleasure. Feelings of excitement can increase enthusiasm and strengthen students' interest to continue on to higher education.

\subsection{Self-efficacy}

The first factor affecting students in continuing to college is self-efficacy. Self-efficacy is self-confidence that with the ability to get things done according to the expected goals. Dale Schunk in (Santrock, 2007) argues that self-efficacy influences students' choices of the activities undertaken.

While according to Ghufron and Rini (2010) defines self-efficacy as someone's evaluation of his ability or competence to perform a task, achieve goals, and overcome obstacles. Next, Bandura

According to Putra (2010) explained that self-efficacy is a person's belief about his ability to carry out a behavior successfully. Meanwhile according to Kreitner (2010) defines self-efficacy as a belief in one's own ability to deal effectively with problem- solving.

Self-efficacy also means believing that you are able to succeed and succeed. They believe that having energy (motivation), resources (situational factors), understanding the right actions (role perception) and competence (ability) to do the task. Meanwhile, according to Bandura in (Wk Lau, 2012) revealed that self-efficacy is the result of social cognitive processes in the form of beliefs and expectations and decisions on its ability to act in order to obtain maximum results.

Based on the explanation from some of the experts, it can be concluded that self-efficacy is a belief in a person towards his ability to do something well according to the expected goals.

\subsection{Parent's social economy}

The next factor influencing one's interest in continuing to college is the socioeconomic parent. Socioeconomic status according to Walter in the journal (Rahayu, 2012) social economic status refers to family income, education and employment. In (2011 Indonesian Public Dictionary) that the status is, position (people, objects, countries and so on).

Socioeconomic is a statement, condition or a statement that can be seen or felt and measured by the human senses (Poerwadarminto, 2002). 
Based on some expert opinions above, it can be concluded that the notion of socioeconomic status in this study is the condition of a family or parent as measured by their level of education, income level, ownership of wealth or facilities as well as the type of work.

Meanwhile, according to Soerjono Soekanto in (Abdulsyani, 2007) social status is a person's place in general in his community that is associated with other people. Thus, social status is one's position in society, which will later determine the views of the community and its role in society.

Based on the explanation from the experts, it can be concluded that the parents' social economy is the economic condition or income of the parents and the family's position in the community.

\subsection{Motivation to learn}

Another factor that is no less influential on a student's interest in continuing to college is learning motivation.

Motivation comes from the word motive which means impulse directed to the fulfillment of psychic and rokhaniah. According to Dalyono (2009) learning motivation is a driving force or impulse owned by humans to do a job that is learning. Meanwhile according to Asrori (2012) Motivation can be interpreted as:

1. Impulse that arises in a person consciously or unconsciously to take an action with a specific purpose.

2. Efforts that can cause a person or group of people to be moved to do something because they want to achieve what they want to achieve.

According to Suhana (2014) learning motivation is power (power motivation), driving force (driving force), or a tool to build a willingness and strong desire in students to learn actively, creatively, effectively, innovatively, and fun in order to change behavior both in cognitive aspects, affective, and psychomotor.

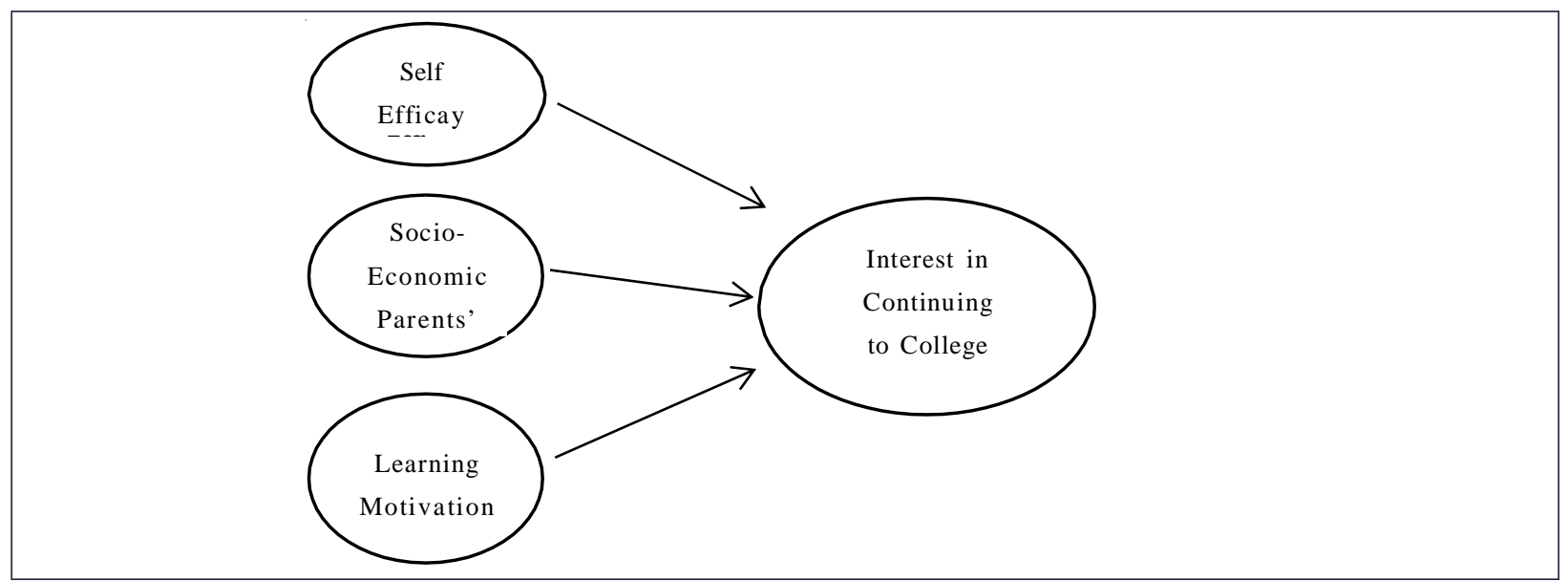

Based on the explanation from some of the experts, it can be concluded that motivation to learn is an encouragement arising from oneself as a driving force to do an activity. Motivation here is discussed is the motivation to learn the activity in question is learning activities.

\section{Hypothesis}

\subsection{Research Hypothesis}

Based on the background of the problem and the mindset above, the hypotheses proposed in this study are:

$H_{1}$ : Self-efficacy (X1) significant effect on interest in continuing to higher education $(Y)$.

$H_{2}$ : Socioeconomic parents (X2) significant effect on interest in continuing to higher education $(Y)$.

$H_{3}$ : Learning Motivation (X3) significant effect on Interest in continuing to higher education (Y).

$H_{4}$ : There is a joint influence between self-efficacy, socioeconomic parents, and learning motivation on interest in continuing to higher education.

\subsection{Research accomplished}

Several studies have been conducted regarding the variables that affect the interest in continuing to college. These variables are self-efficacy, parents' social economy and learning motivation. According to Afri Subarkah (2018) states that there is a positive and significant influence on parents' socioeconomic status, self-efficacy on the interest in continuing to college in class XII XMA Negeri 1 Kejobong academic year 2017/2018. 
In line with Afri Subarkah according to Muhammad Amiqul Haq (2016) based on the research it was found that the interest in continuing studies to tertiary institutions was influenced by learning achievement, parents' socioeconomic conditions, and self-efficacy. The higher student achievement and self- efficacy supported by good socioeconomic conditions of the family, the interest of students to continue their studies to college will also increase.

As for the variable of learning motivation, the results of research conducted by Yogi Farmesa (2017) shows that there is a positive and significant influence between learning motivation and parents' socioeconomic status on the interest in continuing their studies to college students in grade XI of Simeulue Cut High School.

Several other studies have also been carried out regarding variables that influence cheating behavior, namely learning motivation, such as research from (Rahmat Ramadhan, 2018). The results showed that there was a significant influence between students' learning motivation on the interests of students of Padang National Vocational School to continue their education to tertiary institutions. The form of the influence of learning motivation on the interest in continuing education to higher education is positive.

From the results of the research that has been presented, it can be seen that there are still variances that affect the interest in continuing to college, therefore researchers want to further examine the other variables that affect the interest in continuing to college, namely self-efficacy, parents' social economy, and motivation to learn about continuing interest in college.

\section{Research methodology}

Based on the problems that the researcher formulated, the purpose of this study was to obtain appropriate and reliable knowledge about influence between self-efficacy, socioeconomic parents, and learning motivation for continuing interest in higher education. The research method used in this study is a survey method, to obtain correct data and in accordance with facts directly from the source with a comparative approach. The data used are primary data for independent variables (self-efficacy, socioeconomic parents, and learning motivation) and $Y$ variables (Interest in Continuing to Higher Education) by looking at the presence or absence of influence between variable $X$ (self-efficacy, socioeconomic parents, and learning motivation) of variable $Y$ (interest in continuing to higher education).

\begin{tabular}{|c|c|c|c|}
\hline \multicolumn{4}{|l|}{ Research Matrix } \\
\hline Variables & Variable concept & Dimension & Indicators \\
\hline $\begin{array}{l}\mathrm{X} 1 \\
\text { efficacy) }\end{array}$ & $\begin{array}{l}\text { Self-efficacy is a belief in a } \\
\text { person towards his ability to } \\
\text { do something well according } \\
\text { to the expected goals. }\end{array}$ & $\begin{array}{l}\text { - Magnitude } \\
\text { - Generality } \\
\text { - Stretchy }\end{array}$ & $\begin{array}{l}\text { 1. Confidence in the ability to take the } \\
\text { actions needed to achieve an outcome. } \\
\text { 2. Having strong self-confidence towards } \\
\text { self-potentialin completing tasks. } \\
\text { 3. Having a fighting spirit and not giving up } \\
\text { easily when experiencing obstacles } \\
\text { incompleting the task. } \\
\text { 4. Have a commitment to completing } \\
\text { academic tasks well }\end{array}$ \\
\hline $\begin{array}{l}\text { X2 (Socioeconomic } \\
\text { parents) }\end{array}$ & $\begin{array}{l}\text { Parent's social economy is } \\
\text { the economic situation or } \\
\text { income of parents and family } \\
\text { position in the community. }\end{array}$ & & $\begin{array}{l}\text { 1. Parents have a fixed income. } \\
\text { 2. Parents can afford to pay for tuition. } \\
\text { 3. Parents have a lot of dependents. } \\
\text { 4. Parents have a permanent job. }\end{array}$ \\
\hline $\begin{array}{l}\text { X3 } \\
\text { (Learning motivation) }\end{array}$ & $\begin{array}{l}\text { Motivation to learn is a drive } \\
\text { that arises from a person as a } \\
\text { driving force to do an } \\
\text { activity. Motivation here is } \\
\text { discussed is the motivation to }\end{array}$ & $\begin{array}{l}\text { - Feeling happy } \\
\text { - Will } \\
\text { - Encouragement }\end{array}$ & $\begin{array}{l}\text { 1. Loves to study both at school and outside } \\
\text { of school } \\
\text { 2. Willing to learn. } \\
\text { 3. Willing to do a good job. } \\
\text { 4. Have the drive to excel. }\end{array}$ \\
\hline
\end{tabular}




\begin{tabular}{|l|l|l|l|}
\hline \multicolumn{1}{|c|}{ Research Matrix } & \multicolumn{1}{|c|}{ Variable concept } & Dimension & \multicolumn{1}{|c|}{ Indicators } \\
\hline \multirow{2}{*}{$\begin{array}{l}\text { Variables } \\
\text { continuing to college) }\end{array}$} & $\begin{array}{l}\text { learn the activity in question is } \\
\text { learning activities. }\end{array}$ & $\begin{array}{l}\text { Interest in continuing to higher } \\
\text { education is the tendency or } \\
\text { desire of students to continue } \\
\text { their studies to higher education } \\
\text { accompanied by feelings of } \\
\text { pleasure. Feelings of excitement } \\
\text { can increase enthusiasm and } \\
\text { strengthen students' interest to } \\
\text { continue on to higher education }\end{array}$ \\
\hline
\end{tabular}

\section{Results and discussion}

\subsection{Analysis of test requirements}

6.1.1. Normality test

\begin{tabular}{|c|c|c|}
\hline \multicolumn{3}{|c|}{ One-Sample Kolmogorov-Smirnov Test } \\
\hline & & Unstandardized residual \\
\hline \multicolumn{2}{|l|}{$\mathrm{N}$} & 200 \\
\hline \multirow[t]{2}{*}{ Normal Parameters $\mathrm{a}, \mathrm{b}$} & The mean & 0.0000000 \\
\hline & Std. Deviation & 1.73265662 \\
\hline \multirow[t]{3}{*}{ Most Extreme Differences } & Absolute & 0.081 \\
\hline & Positive & 0.067 \\
\hline & Negative & -081 \\
\hline \multicolumn{2}{|l|}{ Statistical Test } & 0.081 \\
\hline \multicolumn{2}{|l|}{ Asymp. Sig. (2-tailed) } & $0.200 \mathrm{c}$ \\
\hline \multicolumn{3}{|c|}{$\begin{array}{l}\text { a. Test distribution is Normal. b. Calculated from data. c. Lilliefors Significance Correction. d. This is the lower } \\
\text { bound of the true significance. }\end{array}$} \\
\hline
\end{tabular}

From the above output obtained nonstandard residual test statistics are Asymp. Sig (2- tailed) increases by 0.200 or can also be written as the probability value $(p$-value $)=0.200>0.05$ means that $H_{0}$ is rejected and $H_{1}$ is accepted. So, the data is normally distributed.

\subsubsection{Reliability test}

\begin{tabular}{|l|c|}
\hline Reliability Statistics & N of Items \\
\hline Cronbach's Alpha & 20 \\
\hline 0.789 & 20 \\
\hline
\end{tabular}

The reliability test of all the variables of this study is evident from Cronbach's alpha value of $0.789>0.7$ overall the variables in this study were reliable. 


\subsubsection{Linearity test}

The basis of this research decision making can be seen from the significant value $>0.05$ then the data has the effect of a linear relationship while if the value is significant $<0.05$ then it does not have the effect of a linear relationship.

\begin{tabular}{|c|c|c|c|c|c|c|c|}
\hline \multicolumn{8}{|l|}{ ANOVA Table } \\
\hline & & & $\begin{array}{c}\text { Sum } \\
\text { of squares }\end{array}$ & df & $\begin{array}{c}\text { Mean } \\
\text { square }\end{array}$ & $F$ & Sig. \\
\hline Higher Education & Between & (Combined) & 29,696 & 13 & 2,284 & 0.731 & 0.731 \\
\hline Interest* & Groups & Linearity & 2,994 & 1 & 2,994 & 0.958 & 0.329 \\
\hline Self-efficacy & & Deviation & 26,702 & 12 & 2,225 & 0.712 & 0.739 \\
\hline \multicolumn{8}{|c|}{ from Linearity } \\
\hline \multicolumn{3}{|c|}{ Within Groups } & 581,324 & 186 & 3,125 & & \\
\hline \multicolumn{3}{|c|}{ Total } & 611,020 & 199 & & & \\
\hline
\end{tabular}

In the output results above show a significant result of $0.739>0.05$ then the variable self-efficacy has a realiable effect on the interest in continuing to college.

\begin{tabular}{|c|c|c|c|c|c|c|c|}
\hline \multicolumn{8}{|l|}{ ANOVA Table } \\
\hline & & & $\begin{array}{c}\text { Sum } \\
\text { of squares }\end{array}$ & df & $\begin{array}{c}\text { Mean } \\
\text { square }\end{array}$ & $F$ & Sig. \\
\hline Interests & Between & (Combined) & 41,450 & 13 & 3,188 & 1,041 & 0.414 \\
\hline Higher Education & Groups & Linearity & 0.641 & 1 & 0.641 & 0.209 & 648 \\
\hline Economy Old & & Deviation & 40,808 & 12 & 3,401 & 1,111 & 0.354 \\
\hline \multicolumn{8}{|c|}{ from Linearity } \\
\hline \multicolumn{3}{|c|}{ Within Groups } & 569,570 & 186 & 3,062 & & \\
\hline \multicolumn{3}{|c|}{ Total } & 611,020 & 199 & & & \\
\hline
\end{tabular}

From the above results that a significant value of $0.354>0.05$ then the economic variables of parents have a reliable influence on the interest in continuing to college.

\begin{tabular}{|c|c|c|c|c|c|c|c|}
\hline \multicolumn{8}{|l|}{ ANOVA Table } \\
\hline & & & $\begin{array}{c}\text { Sum } \\
\text { of squares }\end{array}$ & df & $\begin{array}{c}\text { Mean } \\
\text { square }\end{array}$ & $F$ & Sig. \\
\hline Higher Education & Between & (Combined) & 20,024 & 11 & 1,820 & 0.5779 & 0.844 \\
\hline Interest* & Groups & Linearity & 1,236 & 1 & 1,236 & 0.393 & 0.531 \\
\hline Motivation to & & Deviation from & 18,788 & 10 & 1,879 & 0.598 & 0.815 \\
\hline Learn & & Linearity & & & & & \\
\hline Within Groups & & & 590,996 & 188 & 3,144 & & \\
\hline Total & & & 611,020 & 199 & & & \\
\hline
\end{tabular}


From the above results that a significant value of $0.815>0.05$ then the variable of learning motivation has a reliable influence on interest in continuing to college.

\subsection{Classic assumption test}

\subsubsection{Multicollinearity test}

Multicollinearity is a condition where the independent variable in the linear regression model of a relationship is perfect or almost perfect. A good regression model is certainly not multicollinearity. Tolerance if the value $>0.1$ and VIF $<10$ then there is no multicollinearity.

\begin{tabular}{|c|c|c|c|c|c|c|c|}
\hline Coefficients $^{\mathbf{a}}$ & \multicolumn{2}{|c|}{$\begin{array}{c}\text { Unstandardized } \\
\text { coefficients }\end{array}$} & $\begin{array}{c}\text { Std. } \\
\text { coeffi. }\end{array}$ & \multicolumn{2}{|c|}{$\begin{array}{c}\text { Collinearity } \\
\text { statistics }\end{array}$} \\
\hline & B & Std. Error & Beta & $\boldsymbol{t}$ & Sig. & Tolerance & VIF \\
\hline $1 \quad$ (Constant) & 20,538 & 1,326 & & 15,486 & 0.000 & & \\
\hline Self-efficacy & 0.143 & 0.071 & 0.207 & 2008 & 0.046 & 0.467 & 2,140 \\
\hline Elderly economy & -0.112 & 0.079 & -150 & $-1,411$ & 0.160 & 0.441 & 2,270 \\
\hline Motivation to learn & -0.053 & 0.069 & -0.064 & -774 & 0.440 & 0.730 & 1,370 \\
\hline
\end{tabular}

Note: ${ }^{a}$ Dependent Variable: High Education Interest.

From the table above, the value of the self-efficacy variable is $0.46>0.10$, so there is no multicol in the regression model, whereas in the parents economic variable the value of the clearance is $0.44>0.10$, so there is no multicol in the regression model. and in the learning motivation variable the tolarance value is $0.73>0.10$, so there is no multicol in the regression model.

To strengthen the results it can be seen in the results of the VIF value, the results of the VIF value on the self-efficacy variable of $2.14<10.00$ then there is no multicol. While the economic variable of parents is $2.27<10.00$, then there is no multicol and the results of the VIF value on the learning motivation variable are $1.37<10.00$, so there is no multicol.

\subsubsection{Heterogeneity test}

Self-efficacy variable significant value of $1.00>0.05$ then there is no symptom of heterogeneity, while in the economic variables of parents significant value of $1.00>0.05$ then there is no symptom of heterogeneity, and variable learning motivation is significant at $1,00>0.05$ then there are no symptoms of heterogeneity.

\begin{tabular}{|c|c|c|c|c|c|}
\hline \multicolumn{7}{|c|}{ Coefficients $^{\mathbf{a}}$} & \multicolumn{2}{|c|}{$\begin{array}{c}\text { Unstandardized } \\
\text { coefficients }\end{array}$} & $\begin{array}{c}\text { Std. } \\
\text { coeffi. }\end{array}$ & $\boldsymbol{t}$ & Sig. \\
\hline & B & Std. Error & Beta & & 1,000 \\
\hline $1 \quad$ (Constant) & $1,168 \mathrm{E}-15$ & 1,326 & & 0.000 & 1,000 \\
\hline Self-efficacy & 0.000 & 0.071 & 0.000 & 0.000 & 1,000 \\
\hline Elderly economy & 0.000 & 0.079 & 0.000 & 0.000 & 1,000 \\
\hline Motivation to learn & 0.000 & 0.069 & 0.000 & 0.000 & \\
\hline
\end{tabular}

Note: a Dependent Variable: High Education Interest. 


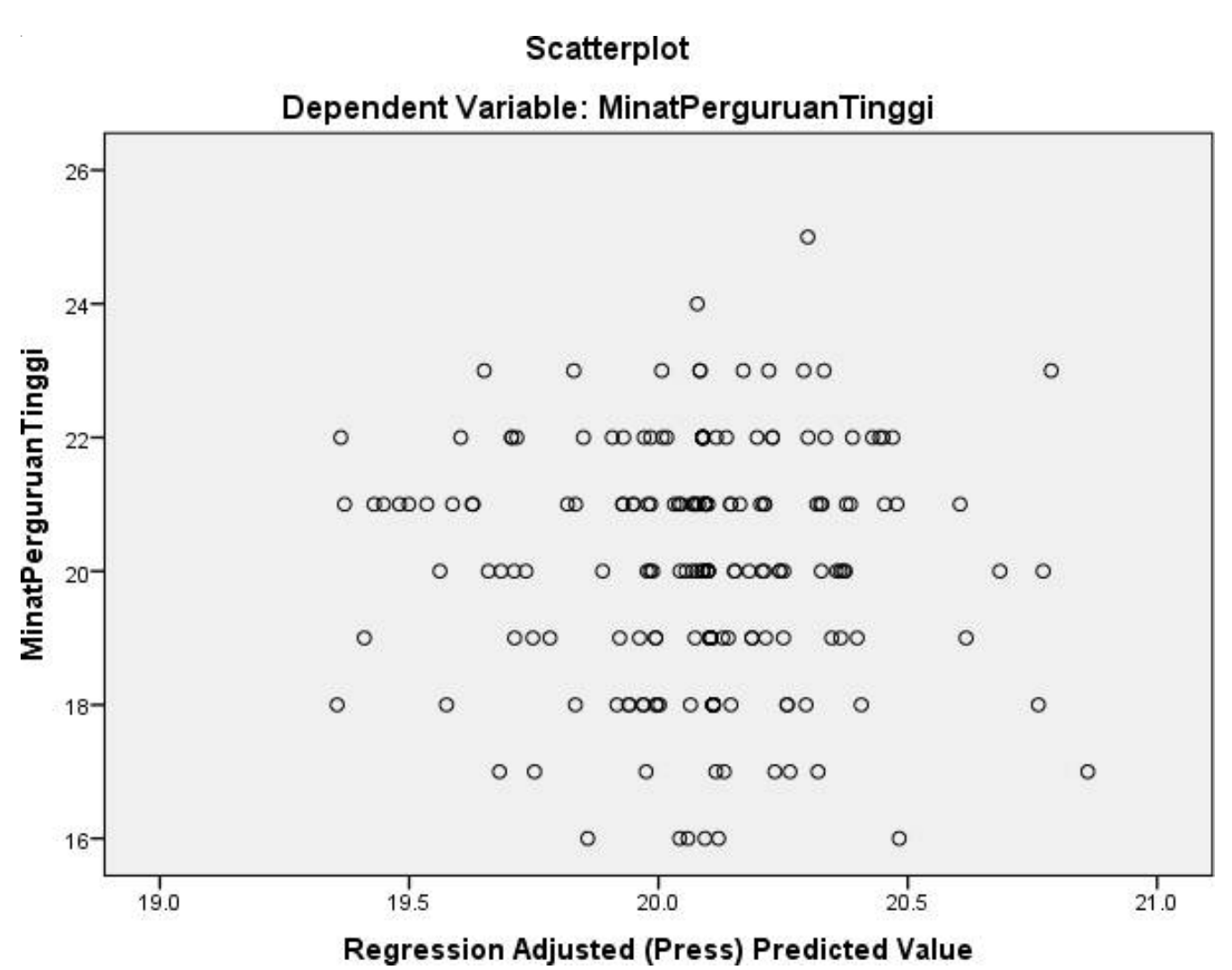

The image above shows the results of calculations using the scatterplot heterogeneity test with SPSS 22.0. Of the scatter image above, note the points irregular and is positioned above and below the number 0 on the $\mathrm{Y}$ axis shows the results of the regression model did not happen heterogeneity.

\subsection{Multiple regression test}

\subsubsection{F-test}

Test $F$ is the regression coefficient test aims to determine whether a significant variable is there any difference or not between the independent variables with the dependent variable. In the table below are the calculations of the $F$-test using SPSS 22.0.

\begin{tabular}{|c|c|c|c|c|c|c|}
\hline \multicolumn{7}{|c|}{ ANOVA $^{a}$} \\
\hline Model & & Sum of squares & df & Mean square & $F$ & Sig. \\
\hline \multirow[t]{3}{*}{1} & Regression & 130,602 & 3 & 14,534 & 5,488 & $0.002^{\mathrm{b}}$ \\
\hline & Residual & 597,418 & 196 & 3,048 & & \\
\hline & Total & 611,020 & 199 & & & \\
\hline
\end{tabular}

According to the $F$-test table shows that the $F$-value is 5,488. Table $F$-values can be found in the statistical table at the 0.05 significance level df 1 (number of variables -1 ) or $4-1=3$, and df $2=n-k-1$ ( $n$ is the data value and $k$ is the value of the independent variable) or $200-3-1=196$. Table $F$ is $2.65 . F$ arithmetic has a value greater than $F$ table that is $5.488>2.65$, so $H_{0}$ is rejected and $H_{1}$ is accepted. The explanation of why self-efficacy, socioeconomic parents and learning motivation simultaneously affect Interest in continuing to higher education. 


\subsection{2. $T$-test}

$T$-test is a calculation carried out by researchers to determine the effect of a partial independent variable on the dependent variable, whether it has a significant effect or not. Here is the calculation:

\begin{tabular}{|l|l|c|c|c|c|c|}
\hline \multicolumn{1}{|l|}{ Coefficients $^{\mathbf{a}}$} & Sum of squares & df & Mean square & $\boldsymbol{F}$ & Sig. \\
\hline Model & & 20,538 & 1,326 & & 15,486 & 0.000 \\
\hline 1 & (Constant) & 0.143 & 0.071 & 0.207 & 2008 & 0.046 \\
\hline & Self-efficacy & 0.187 & 0.051 & 0.174 & 3,411 & 0.000 \\
\hline & Elderly economy & 0.153 & 0.069 & 0.164 & 2,774 & 0.040 \\
\hline
\end{tabular}

Note: a Dependent Variable: High Education Interest.

Self-efficacy variable significant value $0.04<0.05$ then $H_{0}$ is rejected and there is an influence between the independent variables on the dependent variable, while in the Parent Economy variable a significant value of $0.00<0.05$ then $H_{0}$ is rejected and there is an influence between the independent variables and learning motivation variable significant value of $0.04<0.05$ then $H_{0}$ is rejected and there is an influence between the independent variables.

Then it can be strengthened by the results of the $t$ value on the self-efficacy variable of $2.00>1.65 t$ table, then the self-efficacy variable has an influence on the variable interest in continuing higher education, while the parent's economic variable is $3.41>1.65$ then it can it is concluded that the parent's economic variable has an influence on the interest in continuing higher education and the learning motivation variable of $2.77>1.65$ it can be concluded that the learning motivation variable has an influence on the interest in continuing higher education.

\subsubsection{Determination coefficient test}

Determination coefficient calculation aims to measure to predict the value of the variable.

\begin{tabular}{|l|c|c|c|c|}
\hline \multicolumn{2}{|l|}{ Summary Model } \\
\hline Model & $\boldsymbol{R}$ & $\boldsymbol{R}^{2}$ & Adjusted $\boldsymbol{R}^{2}$ & Std. error of the estimate \\
\hline 1 & $0.19 \mathrm{a}$ & 0.082 & 0.037 & 1,746 \\
\hline
\end{tabular}

Can be seen in the $R^{2}$ table of 0.082 can be interpreted that the value of the variable self-efficacy, parental economy and learning Mmotivation affects the regression model. So the influence of the independent variable is the result expressed in a percentage that is $8.2 \%$ while the remaining $91.8 \%$ is influenced by other factors not examined in this study.

\section{Exploratory Factor Analysis (EFA)}

EFA is an analysis to classify items or variables based on the recovery which the EFA test is measured by using factor analysis. Calculated by redaction-factor dimension.

\begin{tabular}{|l|c|}
\hline \multicolumn{2}{|l|}{ a. Self-efficacy (X1) } \\
\hline \multicolumn{2}{|l|}{ Component Matrix } \\
\hline & Component \\
\hline & 1 \\
\hline SE5 & 0.779 \\
\hline SE4 & 0.772 \\
\hline SE3 & 0.767 \\
\hline SE2 & 0.725 \\
\hline SE1 & 0.669 \\
\hline Extraction Method: Principal Component Analysis. \\
\hline a. 1 Component extracted; b. Parents socioeconomic (X2) \\
\hline
\end{tabular}

\begin{tabular}{|l|c|}
\hline \multicolumn{2}{|l|}{ b. Parents Socioeconomic (X2) } \\
\hline Component Matrix \\
\hline & Component \\
\hline & 1 \\
\hline EOT2 & 0.838 \\
\hline EOT5 & 0.791 \\
\hline EOT1 & 0.768 \\
\hline EOT4 & 0.684 \\
\hline EOT3 & 0.455 \\
\hline Extraction Method: Principal Component Analysis. \\
\hline a. 1 component extracted. \\
\hline
\end{tabular}




\begin{tabular}{|l|c|}
\hline \multicolumn{2}{|l|}{ c. Learning motivation (X3) } \\
\hline Component Matrix \\
\hline & Component \\
\hline & 1 \\
\hline MB2 & 0.814 \\
\hline MB4 & 0.808 \\
\hline MB3 & 0.749 \\
\hline MB5 & 0.728 \\
\hline MB1 & 0.640 \\
\hline Extraction Method: Principal Component Analysis. \\
\hline a. 1 component extracted. \\
\hline
\end{tabular}

\begin{tabular}{|l|l|}
\hline \multicolumn{2}{|l|}{ d. Interest in continuing to higher education (Y) } \\
\hline Component Matrix \\
\hline & \multicolumn{1}{|c|}{ Components } \\
\hline & 1 \\
\hline MPT 5 & -685 \\
\hline MPT 4 & 0.523 \\
\hline MPT 1 & 0.435 \\
\hline MPT3 & \\
\hline MPT2 & 456 \\
\hline Extraction Method: Principal Component Analysis. \\
\hline a. 2 components extracted. \\
\hline
\end{tabular}

\section{Comfirmatory Factor Analysis (CFA)}

This study used a technique of Structural Equation Modeling (SEM) using AMOS 22.

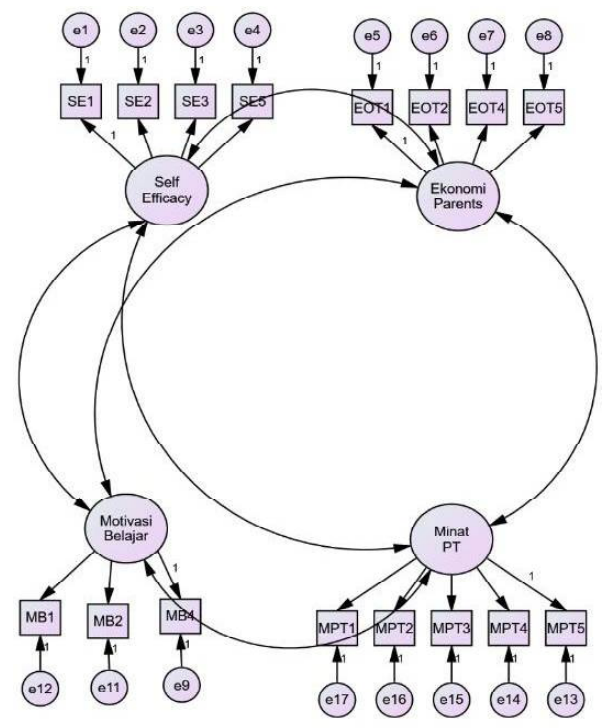

\begin{tabular}{|l|c|c|c|c|c|}
\hline \multicolumn{7}{|l|}{ CMIN } & NPAR & CMIN & DF & P. & CMIN/DF \\
\hline Model & 38 & 120,049 & 98 & 0.065 & 1,225 \\
\hline Default model & 136 & 0.000 & 0 & & \\
\hline Saturated model & 16 & 747,642 & 120 & 0.000 & 6.230 \\
\hline Independence model & &
\end{tabular}

RMR, GFI

\begin{tabular}{|l|c|c|c|c|l|}
\hline Model & RMR & GFI & AGFI & PGFI & \\
\hline Default model & 0.024 & 0.930 & 0.903 & 0.670 & \\
\hline Saturated model & 0.000 & 1,000 & & & \\
\hline Independence model & 0.100 & 0.546 & 0.485 & 0.482 & \\
\hline
\end{tabular}


Based on the above table shows that CMIN / DF of $1,225<2$ and the $p$-value is $0.065>0.05$ then the model fit is acceptable. GFI amounted to 0.930 AGFI is 0.903 and PGFI is 0.607.

\section{Expronatory Structural Model (SEM)}

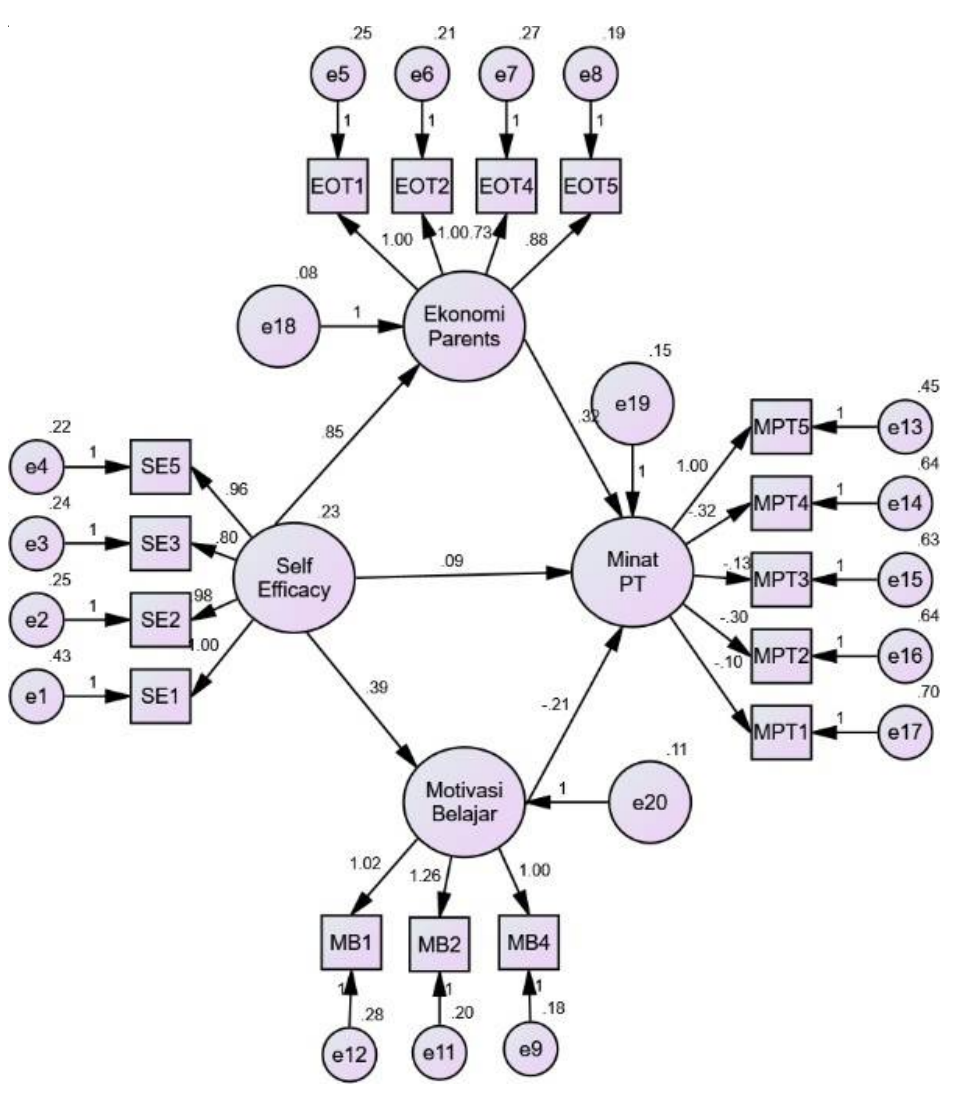

Regression Weights: (Group number 1 - Default model)

\begin{tabular}{|lll|c|c|c|c|l|}
\hline & & & Estimate & SE & CR & P. & Results \\
\hline Economy_Parents & $<-$ & Self_Efficacy & 322 & 292 & 1,102 & $* * *$ & received \\
\hline Motivation to learn & $<-$ & Self_Efficacy & 0.210 & 0.200 & 1,051 & $* * *$ & received \\
\hline Interest_PT & $<--$ & Economy_Parents & 0.847 & 0.131 & 6,478 & $* * *$ & received \\
\hline Interest_PT & $<--$ & Motivation to learn & 0.386 & 0.088 & 4,367 & $* * *$ & received \\
\hline Interest_PT & $<--$ & Self_Efficacy & 0.93 & 0.324 & 288 & 0.773 & rejected \\
\hline
\end{tabular}

From the table above it can be seen that the variable $\mathrm{X}$ affects the variable $\mathrm{Y}$ except self-efficacy does not affect the Interest in continuing to higher education for $P$ more than 0.001 .

\section{Conclusion}

This study aims to examine the factors that influence interest in continuing to higher education with the variables of selfefficacy, social economic parents and learning motivation. The sample used in this study amounted to 200 respondents. For data processing using SPSS 22.0 and AMOS 22.0. After the researchers conducted an analysis of the effect of selfefficacy, social economic parents and learning motivation of interest in continuing to higher education can be concluded as follows:

1. $H_{1}$ indicates that the variable economic parents has a critical value ratio $(C R)$ of $6.478>1.96$ and $P 0.000<0.05$ then has a positive and significant impact on interest in continuing to higher education. 
2. $H_{2}$ indicates that the variable learning motivation has a critical value ratio $(C R)$ of $4.367>1.96$ and $P 0.000<$ 0.05 then has a positive and significant impact on interest in continuing to higher education.

3. $\mathrm{H}_{2}$ indicates that the variable self-efficacy has a critical value ratio (CR) of $0.288<1.96$ and P $0.773>0.05$ then do not have a positive and significant impact on interest in continuing to higher education.

\section{References}

Afri Subarkah, A.N. (2018). The influence of parents social economic status, self efication, and career guidelines against continuing interests to higher education in high school students in kejobong. Economic education analysis Journal.400-414.

Anthony, B., Kamaludin, A., Romli, A., Raffei, A.F.M., Phon, D.N.A.L.E., Abdullah, A., and Ming, G.L. (2020). Blended learning adoption and implementation in higher education: a theoretical and systematic review. Technology, Knowledge and Learning, 1-48.

Asrori, Moh. (2012). Psikologi Pembelajaran. Bandung: Wacana Prima.

Dalyono, M. (2009). sikologi Pendidikan, Cet Ke-5. Jakarta: Renika Cipta.

Djali (2012). Educational psychology. Jakarta: Earth Literacy.

Gerungan. (2009). Psikologi Sosial (Edisi Ketiga). Bandung: PT. Refika Aditama.

Ghufron, M.N., and Risnawita S.R. (2010). Teori-teori Psikologi. Ar Ruz Media :YogJakarta.

Kreitner, K.D. (2010). Organizational behavior. New York: Mcgraw-Hill.

Muhammad Amiqul Haq, R.S. (2016). The influence of learning achievement, social economic condition of parents and self efficacy on interests of continuing studies to college students of ips students. Economic Education Analysis Journal, 1036-1045.

Muhammad Fathurohman, S. (2012). Learning and learning: helps improve learning quality according to national standards. Yogyakarta: Terrace.

Muhibin, S. (2009). Psychology of learning. Jakarta: PT Raja Grafindo Persada.

Nike Pratiwi Suciningrum, E.S. (2015). The effect of parents's socio-economic status and learning motivation on interest in continuing study in higher education in class xi of pusaka 1 high school jakarta. Journal of Economic And Business Education.

Poerwadarminta, W. (2002). Kamus Bahasa Indnesia, balai pustaka. Jakarta.

Rahayu, W.P. (2012). Analysis of educational intensity by parents in children's learning activities, parents' socioeconomic status on student motivation and student learning achievement. Journal of Education and Learning, 65-71.

Rahmat Ramadhan, M.A. (2018). The influence of parents social economic status and learning motivation toward interests of continuing studies to college. Ecogen. 1(1), 140-147.

Sadirman. (2014). Interaction and teaching and learning motivation. Jakarta: Rajawali press.

Schunk, D. H. (1991). Self-efficacy and academic motivation. Educational Psychologist, 26(3-4), 207-231.

Sardiman, A. (2011). Interaction and teaching and learning motivation. Jakarta: PT Raja Grafindo.

Slameto (2010). Learning and factors that influence it. Jakarta: Rineka Cipta.

Suhana, C. (2014). Learning strategy concepts. Bandung: PT. Refika Aditama.

Subiyakto, A., Ahlan, A.R., Kartiwi, M., and Putra, S.J. (2016). Measurement of the information system project success of the higher education institutions in Indonesia: a pilot study. International Journal of Business Information Systems, 23(2), 229-247.

Tambunan, H. (2018). The Dominant Factor of Teacher's Role as a Motivator of Students' Interest and Motivation in Mathematics Achievement. International Education Studies, 11(4), 144-151.

Yogi Farmesa, H.A. (2017). The influence of learning motivation and the social economic status of parents on interests of continuing study. Fkip.Geography Education Student Scientific Journal Unsyiah. 2(2), 146-155.

Zee, M., and Koomen, H.M.Y. (2016). Teacher self-efficacy and its effects on classroom processes, student academic adjustment, and teacher well-being: A synthesis of 40 years of research. Review of Educational Research, 86(4), 981-1015.

Cite this article as: Nabilla Hanum Erwananda and Osly Usman, M. Bus (2021). The influence of selfefficacy, social economics of parents and learning motivation toward interests of continuing to higher education. International J ournal of E ducation and Teaching. 1(1), 29-41. doi: 10.51483/ IJEDT.1.1.2021.29-41. 